\title{
Cushing syndrome due to macronodular adrenal hyperplasia
}

INSERM

\section{Source}

INSERM. (1999). Orphanet: an online rare disease and orphan drug data base. Cushing syndrome due to macronodular adrenal hyperplasia. ORPHA:189427

ACT H-independent macronodular adrenal hyperplasia (AIMAH) is a rare cause of Cushing syndrome (CS; see this term) characterized by nodular enlargement of both adrenal glands (multiple nodules above $1 \mathrm{~cm}$ in diameter) that produce excess cortisol and features of adrenocorticotropic hormone (ACTH) independent CS (see this term). 